\title{
Analisis Availabilitas Perusahaan Pythalic Anhydride Berdasarkan Persediaan Spare Part dan Penyangga
}

\author{
Nurhadi Siswanto*, Nabila Yuraisyah Salsabila, Oryza Akbar Rochmadhan, Erwin Widodo \\ Departemen Teknik Sistem dan Industri, Institut Teknologi Sepuluh Nopember \\ Jl. Raya ITS, Surabaya, Jawa Timur, 60111 \\ *Corresponding Author: siswanto@ie.its.ac.id
}

\begin{abstract}
ABSTRAK
Penelitian ini akan membahas perusahaan kimia yang memproduksi Pythalic Anhydride (PA) di Indonesia. Perusahaan ini memiliki kapasitas 70.000 Metric Ton Per Year (MTPY). Selama 2017, total waktu produksi adalah $6.699,8$ jam atau rata-rata 23 hari. Namun, dibandingkan dengan kapasitas produksi, perusahaan hanya dapat memenuhi permintaan dalam waktu 20 hari tiap bulannya. Waktu produksi minimum diperlukan untuk mencapai layanan pelanggan yang optimal dan biaya minimum. Perbedaan antara kapasitas dan kondisi yang ada disebabkan oleh penutupan pabrik. Penutupan pabrik disebabkan oleh kehabisan persediaan material dan kerusakan mesin. Frekuensi penutupan pabrik relatif tinggi. Selama 2014 hingga 2017, pabrik ditutup 48 kali dengan MTTF 3,1 hari dan MTTR 23 jam. Analisis reliability, availability, dan maintainability (RAM analysis) dilakukan untuk mengatasi masalah ini. Secara khusus, penelitian ini akan fokus pada pengembangan skenario dengan melakukan percobaan pada persediaan penyangga suku cadang untuk mengurangi waktu produksi dan meningkatkan availabilitas. Pendekatan simulasi digunakan dalam penelitian ini untuk memodelkan perilaku stokastik. Berdasarkan hasil percobaan, waktu produksi berkurang 232,7 jam dan availabilitas menjadi 0,8996 . Analisis keuntungan dan biaya dapat dilakukan pada penelitian selanjutnya untuk mendapatkan solusi optimal.
\end{abstract}

Kata kunci: Availabilitas, Simulasi Kejadian Diskret, Manajemen Persediaan

\section{Analysis of the Availability of Pythalic Anhydride Company Based On Spare Parts and Buffer Supplies}

\begin{abstract}
This study will discuss a chemical company that produces Pythalic Anhydride (PA) in Indonesia. This company has a capacity of 70,000 Metric Ton Per Year (MTPY). During 2017, total production time was 6,699.8 hours or the average per month was 23 days. However, compared to the production capacity, the company only can fulfill the demand in 20 days every month. The minimum production time is required to reach optimal customer service and minimum cost. The difference between the capacity and the existing condition is caused by the plant shutdown. Plant shutdown is caused by the material stock out and machine failures. The shutdown frequency is relatively high. During 2014 until 2017, the plant shutdown occurred 48 times with MTTF 3.1 days and MTTR 23 hours. Reliability, availability, and maintainability analysis (RAM analysis) is performed to overcome this problem. Specifically, this study will focus on developing scenarios by conducting the experiments to spare part buffer inventory to decrease production time and increase availability. The simulation approach is used in this paper to model the stochastic behavior. Based on the experiment result, the production time was decreased by 232.7 hours and result in 0.8996 availability. The benefit and cost can be further analyzed in the future to provide an optimal solution.
\end{abstract}

Keywords: Availability, Discrete Event Simulation, Inventory Management 


\section{Pendahuluan}

Menurut laporan nilai ekspor-impor industri pengolahan pada Bulan Januari 2017, nilai ekspor bahan kimia dan barang dari bahan kimia menempati peringkat kedua di Indonesia. Sedangkan nilai impor bahan kimia dan barang dari bahan kimia menempati peringkat pertama di Indonesia. Berdasarkan hal ini, dapat disimpulkan bahwa industri bahan kimia merupakan industri yang memiliki potensi yang sangat tinggi bagi perekonomian di Indonesia. Namun, kebutuhan bahan kimia di Indonesia masih belum bisa dipenuhi sepenuhnya oleh pasar domestik (Kementrian Perindustrian Indonesia, 2017).

Penelitian ini akan membahas tentang sebuah perusahaan yang bergerak di bidang kimia yang memproduksi Pythalic Anhydride (PA). PA merupakan bahan campuran resin pada proses produksi cat dan plastik. Perusahaan ini memiliki kapasitas produksi sebesar 70.000 Metric Ton Per Year (MTPY) dengan rata-rata realisasi produksi pada tahun 2017 adalah sejumlah 4.967,61 Ton setiap bulan. Pada tahun 2017, total waktu produksi perusahaan ini adalah 6699,8 jam yang berarti rata-rata waktu produksi dalam setiap bulannya adalah 23 hari. Namun berdasarkan kapasitas produksi, memproduksi selama 20.69 hari setiap bulan. Pada penelitian ini, waktu produksi yang dimaksud adalah waktu yang dibutuhkan sebuah fasilitas industri proses untuk memenuhi demand produksi yang meliputi berbagai batasan yang dapat menunda, mengganggu, atau memperlambat produksi seperti down time produksi dan penurunan laju produksi. Perbedaan kapasitas dan realisasi produksi ini disebabkan karena terjadinya penutupan pabrik. Penutupan pabrik dapat disebabkan karena persediaan habis dan kerusakan mesin.

Frekuensi penutupan pabrik cukup tinggi. Selama tahun 2014 hingga 2017 terjadi 48 kali penutupan pabrik dengan mean time to failure (MTTF) sebesar 31,1 hari dan mean time to repair (MTTR) sebesar 23 jam. Kerusakan mesin disebabkan karena adanya gangguan pada sistem mekanik, sistem listrik, sistem instrumentasi, dan pasokan listrik.

Berdasarkan permasalahan tersebut, maka strategi yang dapat diterapkan adalah dengan meningkatkan availabilitas. Analisis reliability, availability, dan maintainability (RAM) adalah sebuah peralatan untuk mengevaluasi kinerja sebuah alat pada tahap berbeda dalam proses perencanaan (Corvaro, Gianchetta, Machetti, \& recanati, 2017). Analisis RAM dapat mengatasi permasalahan operasional dan keamanan dengan tujuan untuk mengidentifikasi elemen sistem dimana tindakan perbaikan dapat dilakukan. Adapun beberapa indikator kinerja yang dapat dihasilkan dari analisis RAM ini, yaitu availabilitas, MTTF, dan MTTR (Faulin, Javier, Angel A. Juan, Sebastian Martorell, \& Jose-Emmanuel Ramires Marquez. 2010). Availabilitas sistem dapat diperbaiki dengan pembelian dan pemasangan alat baru, atau melakukan perawatan pada peralatan yang masih memiliki kondisi yang baik (Sabouhi, Abbaspour, Fotuhi-Firuzabad, \& Dehghanian, 2016). Selain kedua kebijakan tersebut, perbaikan availabilitas sistem juga dapat dilakukan dengan menerapkan kebijakan pengendalian persediaan spare part (Jiang, Chen, \& Zhou, 2015; Zhu, Jaarsveld, \& Dekker, 2020) dan persediaan penyangga (Sleptchenko \& van der Heijden, 2016; Sheikh-Zadeh, Farhangi, \& Rosetti , 2020).

Keandalan, availabilitas, dan maintainabilitas merupakan tiga parameter sistem yang memiliki pengaruh signifikan terhadap biaya siklus hidup sebuah sistem. Keandalan didefinisikan sebagai kemampuan sebuah sistem untuk beroperasi sesuai dengan fungsinya dalam jangka waktu tertentu. Sedangkan maintainabilitas adalah probabilitas untuk mendapatkan kembali kondisi awalnya setelah terjadi kerusakan (Agrawal, Murthy, \& Chattopadhyaya, 2019).

Beberapa pendekatan telah dilakukan untuk melakukan analisis RAM, seperti pohon kejadian, fault tree analysis, reliability centered maintenance, dan pemodelan Markov. Analisis RAM dapat dilakukan dengan menentukan komponen kritis yang 
memiliki availabilitas terendah dalam sistem Klasifikasi ABC dan pemodelan simulasi dapat dilakukan dalam analisis kuantitatif. Setelah menentukan komponen kritis, dilakukan analisis skenario dengan menerapkan strategi maintenance persediaan spare part pada komponen kritis tersebut (Wang, Zhang, Yoon, \& Yu, 2019). Agrawal, Murthy, \& Chattopadhyaya, (2019) menerapkan analisis RAM dengan pemodelan Markov. Analisis RAM ini diimplementasikan untuk mengevaluasi keandalan, availabilitas, dan maintainabilitas pada EPBTBM (Earth Pressure Balance Tunnel Boring Machine) di India. Ahmadi et al., (2019) melakukan analisis RAM dengan berbagai pendekatan statistik, yaitu dengan mengevaluasi frekuensi kerusakan dengan diagram Pareto, diagram Plot untuk mengevaluasi kecenderungan komponen, dan scatter plot untuk mengevaluasi waktu antar kerusakan dan waktu untuk perbaikan. Kaczor, iynarski, \& Szkoda (2016) menerapkan simulasi Monte Carlo dan Reliability Block Diagram (RBD) untuk memverifikasi tingkat integritas keamanan pada sebuah sistem keamanan. (Fiondella, Lin, Pham, Chang, \& Li, 2017) mengembangkan model untuk meningkatkan keandalan dengan mempertimbangkan sistem yang bersifat independen dan dependen.

Pada penelitian ini, akan dilakukan eksperimen pada persediaan spare part dan penyangga untuk mencapai target parameter yang diharapkan. Berdasarkan kondisi eksisting, kebijakan persediaan spare part yang diterapkan adalah review kontinu dengan parameter $S, s$. $S$ adalah notasi untuk target level atau nilai maksimum stok spare part, sedangkan $s$ merepresentasikan nilai ROP atau batas pemesanan spare part. Apabila tingkat stok kurang dari nilai $s$ maka pemesanan harus dilakukan. Eksperimen pada persediaan spare part diharapkan dapat meningkatakan availabilitas dengan meminimasi nilai MTTR. Eksperimen pada nilai $S, s$ akan dilakukan untuk memastikan spare part tersedia pada saat terjadi down time. Persediaan penyangga tersedia pada beberapa titik produksi. Pada penelitian ini, eksperimen pada persediaan penyangga akan dilakukan dengan menentukan stok awal periode produksi. Tujuan eksperimen pada persediaan penyangga adalah untuk menghindari terjadinya material starvation dan blocking apabila mesin gagal (Gebennini, Grassi, Fantuzzi, \& Rimini, 2017).

Menurut Faulin, Javier, Angel A. Juan, Sebastian Martorell, \& Jose-Emmanuel Ramires Marquez (2010)., terdapat dua metode untuk melakukan analisis RAM, yaitu dengan pendekatan analitis dan pendekatan simulasi. Pendekatan analitis dilakukan dengan merepresentasikan sistem dengan model matematis (Faulin, Javier, Angel A. Juan, Sebastian Martorell, \& Jose-Emmanuel Ramires Marquez. 2010). Metode ini menggunakan input parameter rata-rata, sehingga jika pendekatan analitis diterapkan pada sistem yang memiliki perilaku acak, maka menghasilkan banyak asumsi dan tidak dapat diterapkan pada sistem aktual. Sedangkan metode simulasi adalah metode yang dapat mengakomodasi perilaku acak dan ketergantungan antar variabel (Faulin, Javier, Angel A. Juan, Sebastian Martorell, \& JoseEmmanuel Ramires Marquez. 2010). Metode ini akan menghasilkan sedikit asumsi sehingga akan lebih layak untuk diterapkan di sistem aktual. Oleh karena itu, metode yang sesuai untuk mengatasi kedua faktor kompleksitas sistem tersebut adalah dengan pendekatan simulasi, khususnya simulasi kejadian diskrit (discrete event simulation/ DES). Simulasi adalah berbagai teknik untuk menirukan sebuah kejadian dari sistem nyata untuk melakukan sebuah penelitian dimana penelitian tersebut terlalu mahal atau tidak mungkin untuk dilakukan di sistem nyata (Trigueiro de Sousa Junior, Montevechi, Miranda, \& Campos, 2019). Dengan menggunakan metode simulasi kejadian diskrit, pengambil keputusan dapat memodelkan dan menghitung kinerja sebuah sistem berdasarkan beberapa alternatif (Rao \& Naikan, 2016).

Penelitian analisis RAM dengan mempertimbangkan aspek stokhastik telah dilakukan pada beberapa penelitian sebelumnya Pada Wen, Han, Yang, \& Kang (2017), dilakukan pengembangan metode baru 
untuk mengukur ketidakpastian berdasarkan derajat kepercayaan pengambil keputusan. Xiang, Rossi, Martin-Barragan, \& Tarim (2018) mengembangkan model mixed-integer non-linear programming (MINLP) untuk mencari solusi sub optimal parameter parameter persediaan (s, S). Nzukam, C., A. Voisin, E. Levrat, D. Sauter, and B. Iung. (2018) melakukan penjadwalan perawatan dengan mempertimbangkan durasi perawatan yang bersifat stokhastik. Pada penelitian tersebut digunakan algoritma Bruss untuk menentukan solusi optimal. Mahdi, Ismahan, Samira Chalah, and Bouchra Nadji. (2017) melakukan analisis keandalan pada sistem fotovolatik (PV) dengan menggunakan pendekatan petri net stokhastik. Pendekatan petri net stokhastik juga dilakukan oleh Elusakin \& Shafiee (2020) untuk melakukan penjadwalan condition based maintenance (CBM) pada blowout preventer (BOP).

Analisis RAM dengan pendekatan simulasi telah dilakukan oleh (Chang, 2017; Chang et al., 2019; Halfpenny, Chabod, Czapski, Aldred, Munson, \& Bonato, 2019; Salsabila, Siswanto, Widodo, \& Rochmadhan, 2019; Salsabila \& Siswanto, 2019). Halfpenny, Chabod, Czapski, Aldred, Munson, \& Bonato (2019) menerapkan simulasi Monte Carlo dengan latin hypercube sampling untuk melakukan uji keandalan pada pendingin udara. Halfpenny, Chabod, Czapski, Aldred, Munson, \& Bonato (2019) melakukan perbandingan antara pendekatan deterministik dan stokhastik. Pada Salsabila \& Siswanto (2019), dilakukan analisis availabilitas dengan mempertimbangkan persediaan spare part. Dari penelitian ini telah diuji bahwa peningkatan persediaan spare part dapat meningkatkan availabilitas secara signifikan. Selain itu, juga telah dilakukan penelitian terkait analisis throughput pada industri proses dengan mempertimbangkan availabilitas produksi (Salsabila, Siswanto, Widodo, \& Rochmadhan, 2019). Pada (Chang, 2017; Chang et al., 2019), dilakukan analisis keandalan pada sistem manufaktur dengan beberapa lini produksi. Eksperimen pada persediaan penyangga dilakukan untuk meningkatkan keandalan sistem. Gebennini,
Grassi, Fantuzzi, \& Rimini (2017) juga melakukan eksperimen persediaan penyangga pada sebuah sistem seri dengan dua stasiunsatu penyangga. Analisis ini dilakukan untuk meningkatkan efisiensi produksi dengan meminimasi terjadinya material starvation dan blocking.

Kontribusi pada penelitian ini adalah pengembangan model simulasi industri proses dengan mempertimbangkan dua jenis eksperimen. Kompleksitas hubungan antar komponen pada industri proses sangat tinggi, sehingga masih belum banyak penelitian yang membahas tentang pemodelan simulasi pada industri proses, terutama pada topik $R A M$ analysis. Penelitian ini bertujuan untuk mengestimasi availabilitas dan waktu produksi pada kondisi eksisting berdasarkan hasil simulasi. Kemudian, berdasarkan hasil estimasi tersebut, akan ditentukan elemen kritis/ bad actor untuk eksperimen. Eksperimen kebijakan persediaan spare part dan persediaan penyangga akan dilakukan pada elemen kritis tersebut. Setelah eksperimen selesai dilakukan, maka selanjutnya adalah dengan mengestimasi hasil eksperimen tersebut dengan model simulasi.

\section{Metodologi}

\subsection{Studi Sistem dan Analisis Permasalahan}

\subsubsection{Elemen sistem}

Elemen sistem dalam konteks simulasi berupa entitas, aktivitas, resources, dan juga kontrol. Berikut ini merupakan elemen-elemen sistem produksi:

- Entitas yang akan dimodelkan pada sistem ini adalah material yang nantinya akan diproses menjadi PA. Dalam kasus ini PA adalah produk yang bersifat kontinu, sehingga dalam simulasi kejadian diskrit ini, PA disimulasikan dalam satuan Ton.

- Simulasi yang dilakukan dalam penelitian ini dimulai dari kedatangan material dari supplier. Setelah material datang, proses dimulai dengan proses oksidasi oleh reactor, kemudian dilanjutkan dengan proses sublimasi oleh condenser dan peralatan yang lain. Setelah itu, dilakukan 
proses distillasi yang kemudian menghasilkan produk PA cair. Produk PA cair ini kemudian disimpan pada pure PA tank untuk sebagian didistribusikan ke konsumen dan sebagian lagi diproses untuk dijadikan PA padat. Proses ini berlangsung di unit pengemasan dengan mesin flaker. Setelah PA padat dikemas dalam bentuk padat, PA padat disimpan pada gudang produk jadi.

- Resource yang disimulasikan pada model ini terdiri atas unit-unit produksi yang akan dibagi menjadi beberapa subsistem, berikut ini merupakan daftar unit yang menjadi resource dalam proses produksi beserta subsistemnya:

- Kontrol yang digunakan dalam sistem ini adalah alur proses produksi dan sistem seri paralel pada blok keandalan.

\subsubsection{Variabel Sistem}

Variabel sistem dari simulasi terdiri dari atas variabel keputusan, variabel respon, dan variabel status. Variabel keputusan pada penelitian ini adalah sistem penjadwalan maintenance. Variabel respon pada penelitian ini adalah keandalan lantai produksi. Sedangkan variabel status pada penelitian ini adalah status dari setiap resource.

\subsubsection{Indikator Kinerja}

Indikator kinerja adalah parameter untuk mengukur keberhasilan suatu sistem agar dapat mencapai tujuan tertentu. Dalam penelitian ini, indikator kinerja yang akan diukur adalah availabilitas produksi dan waktu produksi. Persamaan (1) merupakan rumus perhitungan availabilitas produksi (Ahmadi et al., 2019):

$A=\frac{M T T F}{M T T F+M T T R}$

dengan:

A = availabilitas produksi

MTTF $=$ mean time to failure

MTTR = adalah mean time to repair

Availabilitas yang dihasilkan dari model simulasi adalah availabilitas pada setiap unit. Persamaan (2) menunjukkan rumus perhitungan availabilitas pada sistem seri (Ahmadi et al., 2019):

$A=\left(A_{o}\right)\left(A_{s}\right)\left(A_{d}\right)\left(A_{b}\right)$

dengan:

$A=$ availabilitas sistem

$A_{o}=$ availabilitas unit oksidasi

$A_{s}=$ availabilitas unit sublimasi

$A_{d}=$ availabilitas unit distilasi

$A_{b}=$ availabilitas unit pengemasan

Sedangkan waktu produksi adalah waktu yang dibutuhkan sebuah fasilitas industri proses untuk memenuhi demand produksi. Waktu produksi tersebut meliputi berbagai halangan yang dapat menunda, mengganggu, atau memperlambat produksi, contohnya adanya unscheduled downtime, seperti permasalahan mekanik dan kerusakan (U.S. Department of Energy, 2014).

\subsection{Pengumpulan Data}

Berikut ini merupakan jenis-jenis data dalam simulasi (Harrel, Gosh, \& Bowden 2004):

- Data struktural meliputi objek pada sistem yang akan dimodelkan. Data ini meliputi jenis mesin, aktivitas produksi, dan lokasi mesin dan peralatan, termasuk penyangga.

- Data operasional adalah data yang menjelaskan bagaimana sebuah sistem beroperasi. Pada penelitian ini, data operasional terdiri atas alur proses produksi, sistem keandalan, dan sistem persediaan.

- Data numerik adalah segala data kuantitatif dari sebuah sistem. Data numerik pada penelitian ini adalah kapasitas, MTTR, MTTF, $S$, $s$, dan laju produksi.

\subsection{Pengolahan Data}

Data-data numerik yang bersifat stokhastik seperti waktu antar kegagalan dan waktu lamanya perbaikan dilakukan fitting distribusi untuk mencari distribusi yang sesuai dengan data historis dan behavior data tersebut. 


\subsection{Pengembangan Skenario}

Skenario akan dikembangkan berdasarkan hasil simulasi dengan kondisi eksisting. Hasil eksperimen pada masing-masing skenario kemudian akan dibandingkan untuk menentukan keputusan yang terbaik.

- Skenario 1: menentukan stock awal buffer pada unit yang memiliki keandalan terendah.

- Skenario 2: memperbaiki kebijakan persediaan spare part untuk meminimasi MTTR.

\subsection{Pengembangan Model Konseptual}

Model konseptual yang akan dibangun adalah flow diagram untuk memodelkan sistem produksi dan persediaan.

\subsection{Model Simulasi}

Model simulasi disusun berdasarkan model konseptual dan hasil fitting distribusi pada tahap pengolahan data. Penulis menyusun model simulasi dengan menggunakan metode simulasi diskrit.

\subsection{Perhitungan Jumlah Replikasi}

Masukan simulasi bersifat acak, sehingga keluaran yang dihasilkan juga bersifat acak. Apabila replikasi hanya dilakukan satu kali, maka hasil simulasi kurang cukup merepresentasikan sistem aslinya. Oleh karena itu, perlu dilakukan beberapa kali replikasi agar data yang dihasilkan cukup merepresentasikan sistem aslinya.

\subsection{Verifikasi dan Validasi Model Simulasi}

Penulis melakukan verifikasi model simulasi untuk memastikan logika model simulasi sudah merepresentasikan model konseptual. Berikut ini merupakan proses verifikasi yang akan dilakukan oleh penulis:

- Menggunakan fasilitas debug pada metode simulasi diskrit.

- Menggunakan animasi untuk menampilkan variabel tertentu dalam sistem simulasi.

Sedangkan validasi dilakukan untuk menguji apakah model sudah merepresentasikan real system. Penulis melakukan validasi dengan membandingkan hasil model simulasi terhadap data historis dengan menggunakan metode statistik inferensi. Jika data hasil simulasi tidak memiliki perbedaan yang signifikan terhadap data aktual, maka model simulasi dapat dikatakan valid.

\subsection{Eksperimen}

Setelah model simulasi sistem eksisting dijalankan, maka langkah selanjutnya adalah melakukan eksperimen terhadap model simulasi tersebut. Eksperimen model ini dilakukan berdasarkan skenario yang telah ditetapkan oleh penulis.

\subsection{Analisis Output}

Pada tahap ini penulis melakukan perbandingan antara sistem eksisting dengan sistem skenario hasil eksperimen. Apabila terdapat perbedaan yang signifikan pada hasil skenario dengan sistem eksisting dan hasil skenario lebih baik, maka sistem skenario dapat diterapkan. Pada tahap ini, apabila KPI masih belum mencapai target, penulis juga dapat mengembangkan skenario lainnya untuk mendapatkan hasil eksperimen yang lebih optimal. Setelah ditentukan skenario yang paling optimal, dilakukan analisis sensitivitas untuk mengetahui perubahan keputusan apabila terjadi perubahan pada faktor tertentu.

\section{Hasil dan Pembahasan}

\subsection{Pengembangan Model}

\subsubsection{Submodel Produksi}

Dalam memodelkan sistem produksi, penulis menerapkan sistem black box, sehingga proses produksi yang disimulasikan hanya berdasarkan unit dan tidak memodelkan masing-masing sub-unit pada pabrik. Penulis memodelkan sistem produksi dengan mempertimbangkan kombinasi terjadinya kegagalan pada saat proses produksi yang telah dijelaskan pada bagian 3.1.1. Gambar 1 menampilkan model konseptual submodel sistem produksi.

Model konseptual yang digunakan dalam memodelkan subsistem produksi unit oksidasi, 
sublimasi, distilasi, dan pengemasan adalah sama. Model dimulai dari input kedatangan material dan kerusakan unit. Submodel produksi berjalan berdasarkan jumlah material yang masuk dan kerusakan unit. Persediaan penyangga berperan dalam mengatur jumlah material yang masuk pada unit tersebut. Kerusakan unit dimodelkan berdasarkan hasil pembangkitan bilangan acak berdasarkan parameter distribusi MTTR dan MTTF.

Tahap selanjutnya adalah menunggu hingga status mesin menjadi 1. Dalam penelitian ini, mesin yang dapat beroperasi disimbolkan dengan angka 1, sedangkan apabila mesin rusak disimbolkan dengan angka 0. Apabila terjadi kerusakan pada saat sebelum proses produksi dimulai, maka produksi tidak dapat dilakukan hingga status mesin menjadi 1, atau dapat beroperasi. Setelah status unit kembali menjadi 1, maka proses produksi dapat dilakukan berdasarkan laju produksi setiap unit.

Pada tahap selanjutnya dilakukan evaluasi waktu kerusakan dengan berbagai kombinasi, di antaranya adalah:

- $w_{2}<t_{1}$ dan $w_{1}<t_{1}$

Kombinasi ini merupakan kerusakan yang tidak terjadi pada rentang waktu produksi. Kejadian kerusakan ini tidak akan mempengaruhi proses produksi, sehingga material dapat diproses pada tahap selanjutnya.

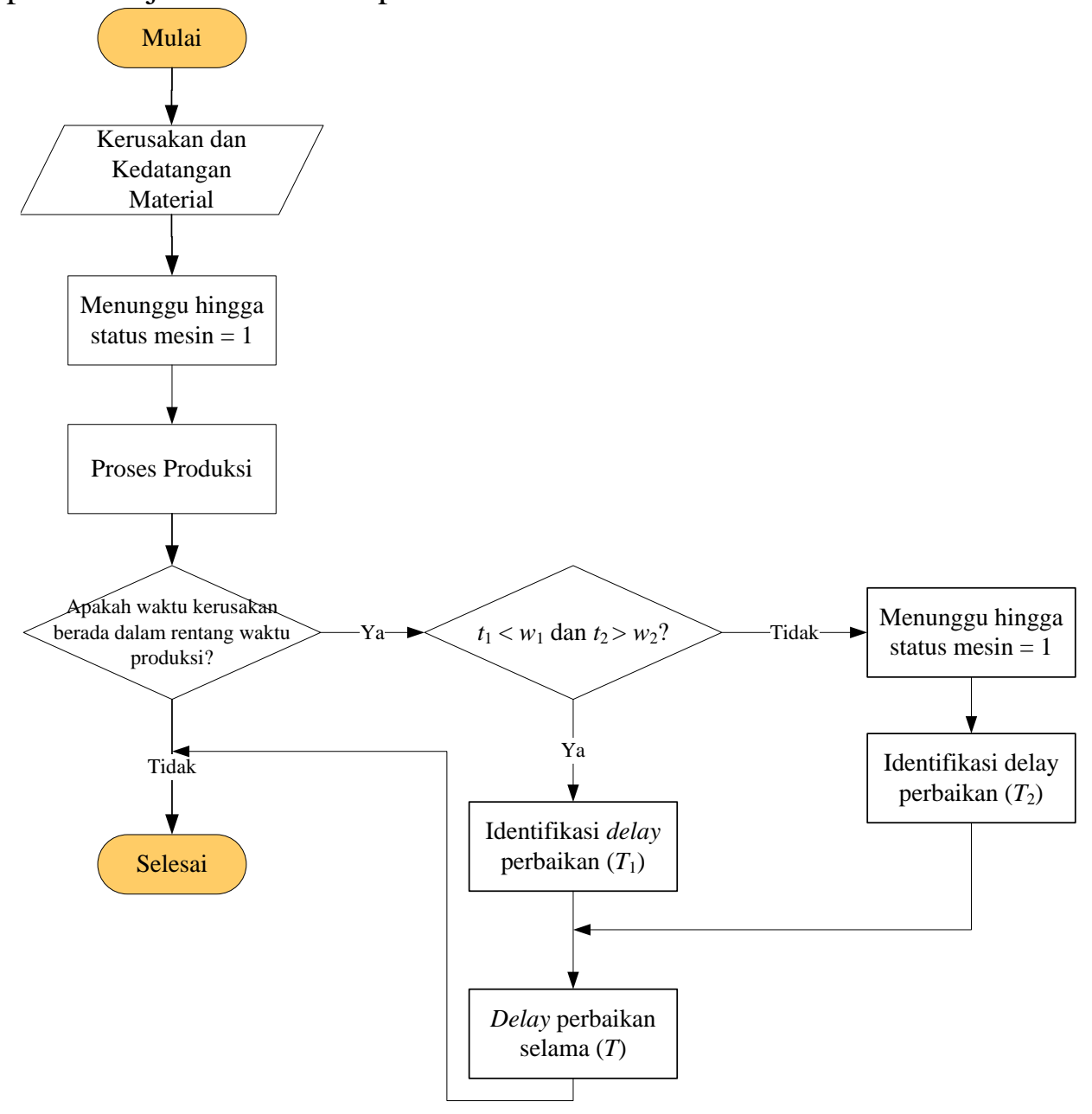

Gambar 1. Submodel Sistem Produksi

- $t_{1}<w_{1}$ dan $t_{2}>w_{2}$

Kombinasi ini merupakan kerusakan yang dimulai setelah proses produksi dimulai dan berakhir sebelum proses produksi berakhir, Pada kombinasi ini, waktu material 36 berada dalam unit produksi bertambah sebesar $T_{1}$. Berikut ini merupakan rumus perhitungan $T_{l}$.

$T_{1}=w_{2}-w_{1}$ 
dengan:

$T_{l}=$ waktu tambahan delay

$w_{1}=$ waktu mulai perbaikan

$w_{2}=$ waktu selesai perbaikan

- $t_{1}<w_{1}$ dan $t_{2}<w_{2}$

Pada kombinasi kerusakan ini, kerusakan dimulai di tengah proses produksi namun hingga waktu produksi yang seharusnya berakhir, kerusakan masih terjadi. Terjadinya kombinasi ini mengakibatkan waktu material berada dalam unit bernilai $T_{2}$. Namun, sebelum dilakukan delay kerusakan,langkah selanjutnya adalah menunggu hingga status unit menjadi 1. Berikut ini merupakan rumus perhitungan $T_{2}$.

$T_{2}=\left(t_{2}-w_{1}\right)$

dengan:

$T_{2}=$ waktu tambahan delay

$w_{1}=$ waktu mulai perbaikan

$t_{2}=$ waktu selesai produksi

Apabila kerusakan terjadi pada rentang waktu produksi, maka akan terjadi delay kerusakan di tengah produksi. Proses ini dilakukan apabila kerusakan terjadi pada rentang waktu produksi. Waktu delay kerusakan ini ditentukan berdasarkan $T_{1}$ dan $T_{2}$ yang telah ditentukan sebelumnya.

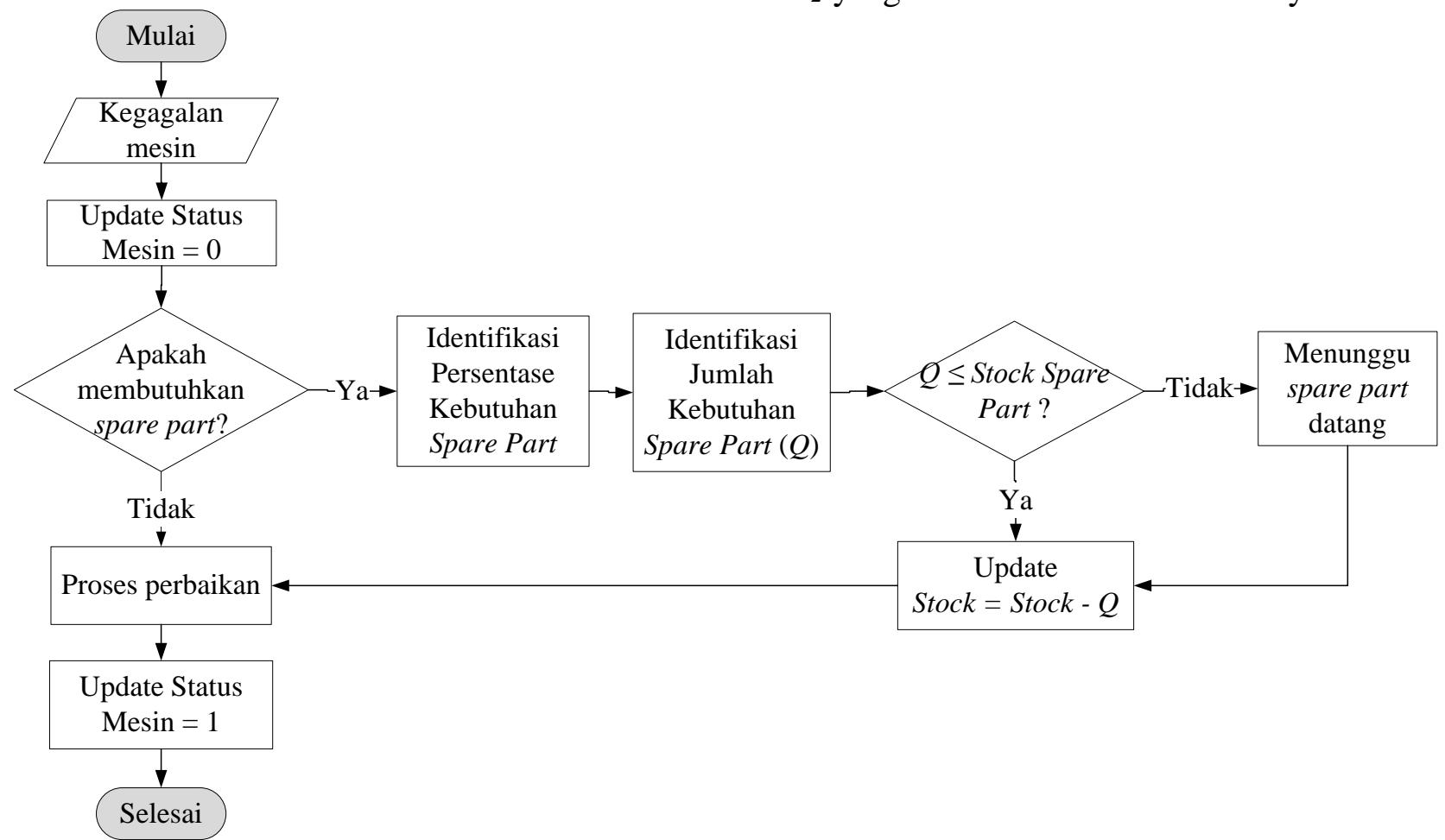

Gambar 2. Submodel Konseptual Pemesanan Spare Part

Seluruh unit produksi terhubung dalam susunan seri, sehingga apabila salah satu unit mengalami kerusakan, maka seluruh sistem tidak dapat beroperasi.

\subsubsection{Submodel Pemesanan Spare Part}

Gambar 2 menunjukkan model konseptual submodel pemesanan spare part. Model ini dimulai dari input data waktu antar kegagalan mesin. Waktu antar kegagalan mesin ini didapatkan dari hasil fitting distribution. Pada model ini, kerusakan direpresentasikan dengan sebuah entitas yang datang dan masuk ke dalam sistem. Setelah kerusakan datang, dilakukan update status mesin menjadi 0 . Kemudian dilakukan evaluasi apakah kerusakan tersebut membutuhkan spare part. Untuk menjawab hal ini, digunakan probabilitas kebutuhan spare part setiap mesin. Apabila membutuhkan spare part, maka proses 
selanjutnya adalah menentukan spare part yang dibutuhkan. Jika tidak membutuhkan spare part, maka proses selanjutnya adalah proses perbaikan. Pada tahap identifikasi jumlah kebutuhan spare part, dilakukan penentuan jumlah spare part yang dibutuhkan untuk proses perbaikan. Penentuan jumlah spare part ini dilakukan berdasarkan data historis kerusakan mesin. Jumlah spare part dinotasikan dengan $Q$. Selanjutnya dilakukan evaluasi apakah posisi persediaan spare part mencukupi kebutuhan spare part. Apabila cukup, maka proses perbaikan dapat dilakukan. Namun apabila tidak, terjadi delay pengiriman spare part. Setelah jumlah spare part mencukupi kebutuhan (persediaan spare part $\geq Q$ ), maka proses perbaikan dapat dilakukan. Kemudian dilakukan pengurangan posisi persediaan spare part sejumlah $Q$. Setelah jumlah spare part terpenuhi, dilakukan perbaikan. Waktu proses perbaikan ditentukan berdasarkan hasil fitting distribution yang telah dilakukan sebelumnya. Setelah mesin selesai diperbaiki, dilakukan update kembali status mesin menjadi 1 .

\subsection{Verifikasi dan Validasi}

\subsubsection{Verifikasi}

Tujuan melakukan verifikasi adalah untuk menghindari terjadinya error pada model simulasi. Terdapat dua jenis error, yaitu semantic error dan syntax error. Syntax error adalah kesalahan penulisan kode atau notasi sehingga model tidak dapat berjalan. Sedangkan semantic error adalah kesalahan logika model sehingga tidak sesuai dengan model konseptual (Harrel, Gosh, \& Bowden 2004). Dalam melakukan verifikasi syntax error, penulis menggunakan fasilitas debug pada metode simulasi diskrit. Dari hasil penggunaan debug tidak terdapat syntax error atau kesalahan penulisan kode atau notasi pada model simulasi. Sedangkan untuk melakukan varifikasi semantic error digunakan fitur animasi yang tersedia pada software simulasi. Animasi yang dimaksud adalah menampilkan variabel dan grafik selama berjalannya simulasi. Variabel yang ditampilkan pada subsistem kegagalan adalah status subsistem, posisi persediaan spare part, dan posisi persediaan spare part yang sedang dikirim.

\subsubsection{Penentuan Jumlah Replikasi}

Langkah pertama adalah menentukan jumlah replikasi awal. Berdasarkan hasil 10 replikasi simulasi, rata-rata waktu produksi dalam satu tahun sebesar 6716,7 jam. Nilai half width $(h w)$ berdasarkan simulasi adalah 126,71. Kemudian $h w$ yang diharapkan dihitung dengan error 5\% yang ditunjukkan pada persamaan (5) dan (6).

$h w=5 \%(6690,80)$.

$h w=334,99$.

Berdasarkan persamaan (5) dan (6), dapat diketahui bahwa $h w$ simulasi masih kurang dari pada $h w$ yang diharapkan. Oleh karena itu, dapat disimpulkan bahwa replikasi sebanyak 10 sudah cukup. Persamaan (7) dan (8) menunjukkan hasil perhitungan jumlah replikasi.

$n^{\prime}=\left[\frac{Z \alpha / 2}{h w}\right]^{2}=\left[\frac{1.96(117,14)}{126,71}\right]^{2}=3,28$

$n^{\prime} \approx 4$

Meskipun jumlah replikasi yang dibutuhkan sebanyak 4 , namun penulis tetap menggunakan jumlah replikasi 10 karena waktu simulasi yang dibutuhkan hanya 0,82 menit.

\subsection{Analisis Model}

\subsubsection{Kondisi Eksisting}

Pabrik PA menggunakan sistem $S, s$ pada kebijakan persediaan spare part. Pemesanan spare part akan dilakukan apabila stock spare part dalam gudang kurang dari $s$ dengan jumlah pemesanan hingga $S$ terpenuhi. Terdapat dua persediaan penyangga pada pabrik ini, yaitu pada unit sublimasi dan unit distilasi. Unit sublimasi berkapasitas 300 ton, sedangkan unit distilasi berkapasitas 1600 ton. Pabrik PA adalah pabrik industri proses yang bekerja selama 24 jam, sehingga apabila terjadi downtime, maka kapasitas produksi akan berkurang. Downtime pabrik dapat diatasi dengan kebijakan spare part yang optimal dan penentuan kapasitas persediaan penyangga 
untuk menghindari terjadinya blocking dan starving.

Berdasarkan hasil simulasi, rata-rata availabilitas sistem adalah 0,884 dan rata-rata waktu produksi selama 6716,7 jam. Selanjutnya dilakukan evaluasi availabilitas sistem pada setiap unit untuk mengetahui unit yang memiliki availabilitas paling rendah. Availabilitas sistem didapatkan dari hasil perhitungan availabilitas setiap unit yang tersusun secara seri.

Rata-rata availabilitas masing-masing unit oksidasi, sublimasi, distilasi, dan pengemasan adalah 90,25\%, 98,90\%, 99,61\%, dan 99,5\%. Berdasarkan hasil simulasi ini, maka dapat disimpulkan bahwa unit oksidasi memiliki availabilitas terendah dalam sistem. Oleh karena itu, penulis akan melakukan eksperimentasi terhadap persediaan spare part dan penyangga pada unit oksidasi. Dari hasil simulasi, didapatkan tiga spare part terendah dalam unit oksidasi, yaitu 001125.4, 001265.8, dan 004881.1, sehingga langkah selanjutnya adalah melakukan skenario pada ketiga spare part tersebut.

Tabel 2 menunjukkan rangkuman stock persediaan penyangga. Berdasarkan hasil simulasi, jumlah stok material pada persediaan penyangga cenderung minimum. Hal ini disebabkan karena kapasitas persediaan penyangga yang cukup tinggi yang mengakibatkan blocking dan starving yang minimum. Kapasitas persediaan penyangga yang tinggi dapat menjadi keuntungan bagi perusahaan, karena perusahaan dapat mengatur jumlah persediaan penyangga yang tersedia pada awal periode produksi. Stock awal persediaan penyangga ini kemudian akan dapat mengatasi permasalahan starving dan blocking pada saat mesin rusak. Sedangkan apabila kapasitas persediaan penyangga terbatas, maka diperlukan penambahan kapasitas persediaan

Tabel 1. Hasil Simulasi Kondisi Eksisting

\begin{tabular}{ccccccc}
\hline Replikasi & $\begin{array}{c}\text { Waktu Produksi } \\
\text { (jam) }\end{array}$ & $\begin{array}{c}\text { Availabilitas } \\
\text { Sistem }\end{array}$ & $\begin{array}{c}\text { Availabilitas } \\
\text { Oksidasi }\end{array}$ & $\begin{array}{c}\text { Availabilitas } \\
\text { Sublimasi }\end{array}$ & $\begin{array}{c}\text { Availabilitas } \\
\text { Distilasi }\end{array}$ & $\begin{array}{c}\text { Availabilitas } \\
\text { Pengemasan }\end{array}$ \\
\hline 1 & 6.372 & 0,931 & 0,946 & 0,994 & 0,990 & 1 \\
2 & 6.839 & 0,864 & 0,888 & 0,982 & 0,996 & 0,994 \\
3 & 6.817 & 0,874 & 0,879 & 0,999 & 1 & 0,995 \\
4 & 6.582 & 0,904 & 0,928 & 0,996 & 0,984 & 0,994 \\
5 & 6.806 & 0,877 & 0,884 & 0,995 & 1 & 0,997 \\
6 & 6.755 & 0,879 & 0,897 & 0,987 & 0,997 & 0,995 \\
7 & 6.508 & 0,915 & 0,924 & 0,998 & 0,998 & 0,994 \\
8 & 6.735 & 0,873 & 0,922 & 0,959 & 0,995 & 0,993 \\
9 & 6.787 & 0,873 & 0,890 & 0,990 & 1 & 0,991 \\
10 & 6.966 & 0,854 & 0,867 & 0,990 & 1 & 0,995 \\
\hline Rata-rata & $6.716,7$ & 0,884 & 0,903 & 0,989 & 0,996 & 0,995 \\
\hline
\end{tabular}

yang akan menghasilkan biaya investasi yang sangat tinggi.

\subsubsection{Pengembangan Skenario}

Spare part 001125.4, 001265.8, dan 004881.1 menghasilkan availabilitas terendah. Ketiga spare part tersebut tidak tersedia pada saat terjadi kegagalan mesin, sehingga mengakibatkan MTTR yang lebih lama karena adanya delay pengiriman spare part. Untuk mengatasi permasalahan ini, maka akan dilakukan perbaikan parameter $S, s$ pada ketiga spare part tersebut. Untuk menentukan nilai $S, s$ yang baru, maka dilakukan analisis jumlah spare part selama simulasi. Pada saat spare part 001125.4 sejumlah 5, dilakukan pemesanan spare part, sehingga pada perancangan skenario $s$ dapat diubah menjadi lebih dari 5, yaitu menjadi 10 dan nilai $S$ diubah menjadi 40 . Parameter $s, S$ spare part 001265.8 adalah 20 dan 100 secara berurutan. Berdasarkan hasil simulasi, pemesanan dilakukan pada saat spare part berjumlah 30 sehingga nilai $s$ dapat diubah menjadi 30 atau lebih. Nilai $s$ diubah menjadi 40 dan nilai $S$ diubah menjadi 120. Pada spare part 004881.1, nilai $s$ dan $S$ adalah 1 dan 4. Jumlah spare part yang dibutuhkan pada setiap kerusakan adalah 4 , sehingga nilai $s$ dapat diubah menjadi 4 atau lebih. Nilai $s$ dan $S$ diubah menjadi 4 dan 8 . 
Tabel 2. Jumlah Stock Persediaan Penyangga

\begin{tabular}{ccccccc}
\hline \multirow{2}{*}{ Replikasi } & \multicolumn{3}{c}{ Buffer Sublimasi } & \multicolumn{3}{c}{ Buffer Distilasi } \\
\cline { 2 - 7 } & Rata-rata & Minimum & Maksimum & Rata-rata & Minimum & Maksimum \\
\hline 1 & 0,126 & 0 & 1 & 1,289 & 0 & 99 \\
2 & 14,434 & 0 & 300 & 0,361 & 0 & 49 \\
3 & 1,695 & 0 & 40 & 0,624 & 0 & 49 \\
4 & 0,038 & 0 & 1 & 0,955 & 0 & 89 \\
5 & 0,057 & 0 & 1 & 0,991 & 0 & 83 \\
6 & 2,357 & 0 & 151 & 0,517 & 0 & 59 \\
7 & 1,113 & 0 & 110 & 0,419 & 0 & 69 \\
8 & 8,548 & 0 & 280 & 0,517 & 0 & 49 \\
9 & 0,059 & 0 & 1 & 1,127 & 0 & 62 \\
10 & 0,094 & 0 & 1 & 0,846 & 0 & 49 \\
\hline Rata-rata & 2,852 & 0 & 88,6 & 0,764 & 0 & 65,7 \\
\hline
\end{tabular}

Tabel 3. Blocking pada Persediaan Penyangga

\begin{tabular}{ccccccc}
\hline \multirow{2}{*}{ Replikasi } & \multicolumn{3}{c}{ Blocking Sublimasi } & \multicolumn{3}{c}{ Blocking Distilasi } \\
\cline { 2 - 7 } & Rata-rata & Minimum & Maksimum & Rata-rata & Minimum & Maksimum \\
\hline 1 & 0 & 0 & 0 & 0 & 0 & 0 \\
2 & 0,218 & 0 & 11 & 0 & 0 & 0 \\
3 & 0 & 0 & 0 & 0 & 0 & 0 \\
4 & 0 & 0 & 0 & 0 & 0 & 0 \\
5 & 0 & 0 & 0 & 0 & 0 & 0 \\
6 & 0 & 0 & 0 & 0 & 0 & 0 \\
7 & 0 & 0 & 0 & 0 & 0 & 0 \\
8 & 0 & 0 & 0 & 0 & 0 & 0 \\
9 & 0 & 0 & 0 & 0 & 0 & 0 \\
10 & 0 & 0 & 0 & 0 & 0 & 0 \\
\hline Rata-rata & 0,022 & 0 & 1,1 & 0 & 0 & 0 \\
\hline
\end{tabular}

Skenario untuk persediaan penyangga adalah dengan menentukan stok penyangga di awal periode. Stok awal ini dapat berfungsi sebagai stok cadangan agar proses produksi dapat berjalan apabila terjadi penutupan pada salah satu unit. Pada penelitian ini stok awal persediaan penyangga ditetapkan sebesar $100 \%$ dari masing-masing kapasitas persediaan penyangga.

\subsubsection{Hasil Eksperimen}

Tabel 4 menunjukkan hasil simulasi dengan skenario perbaikan persediaan spare part 001125.4, 001265.8, 004881.1 dan persediaan penyangga dengan stok awal $100 \%$. Berdasarkan Tabel 4, dihasilkan rata-rata waktu produksi selama $6.483,9$ jam atau 22,5 hari setiap bulan. Pada skenario ini, waktu produksi berkurang selama 232,7 jam.

$\Delta t=t_{\text {eksisting }}-t_{\text {eksperimen }} \ldots \ldots \ldots \ldots \ldots \ldots \ldots \ldots$
$\Delta t=6716,7-6,483,9=232,8 \mathrm{jam}$

dengan:

$\Delta t=$ selisih waktu produksi

$t_{\text {eksisting }}=$ waktu produksi eksisting

$t_{\text {eksperimen }}=$ waktu produksi hasil eksperimen 
Tabel 4. Hasil Eksperimen

\begin{tabular}{ccccccc}
\hline Replikasi & $\begin{array}{c}\text { Waktu } \\
\text { Produksi (jam) }\end{array}$ & $\begin{array}{c}\text { Availabilitas } \\
\text { Sistem }\end{array}$ & $\begin{array}{c}\text { Availabilitas } \\
\text { Oksidasi }\end{array}$ & $\begin{array}{c}\text { Availabilitas } \\
\text { Sublimasi }\end{array}$ & $\begin{array}{c}\text { Availabilitas } \\
\text { Distilasi }\end{array}$ & $\begin{array}{c}\text { Availabilitas } \\
\text { Pengemasan }\end{array}$ \\
\hline 1 & 6.615 & 0,8840 & 0,9022 & 0,9881 & 0,9979 & 0,9937 \\
2 & 6.464 & 0,9020 & 0,9201 & 0,9921 & 0,9950 & 0,9931 \\
3 & 6.668 & 0,8670 & 0,8774 & 0,9972 & 0,9979 & 0,9930 \\
4 & 6.511 & 0,9024 & 0,9177 & 0,9904 & 0,9986 & 0,9942 \\
5 & 6.253 & 0,9268 & 0,9395 & 0,9958 & 0,9984 & 0,9922 \\
6 & 6.428 & 0,9150 & 0,9261 & 0,9995 & 0,9963 & 0,9922 \\
7 & 6.138 & 0,9574 & 0,9714 & 0,9947 & 0,9972 & 0,9936 \\
8 & 6.645 & 0,8787 & 0,8976 & 0,9909 & 0,9914 & 0,9965 \\
9 & 6.371 & 0,9043 & 0,9281 & 0,9834 & 0,9973 & 0,9935 \\
10 & 6.746 & 0,8580 & 0,8764 & 0,9893 & 0,9963 & 0,9933 \\
\hline Rata-rata & $6.483,9$ & 0,8996 & 0,9157 & 0,9921 & 0,9966 & 0,9935
\end{tabular}

Berdasarkan hasil uji hipotesis student $t$, hasil skenario ini menunjukkan perbedaan signifikan pada waktu produksi. Hal ini dapat dibuktikan dari hasil $t$ stat yang berada diluar interval $t$ critical two tail. Sedangkan availabilitas sistem meningkat menjadi 0.8996 yang semula bernilai 0,8843 .

Gambar 3 menunjukkan grafik stok persediaan spare part 001125.4 setelah eksperimen diterapkan. Selama 1.100 hari $( \pm 3$

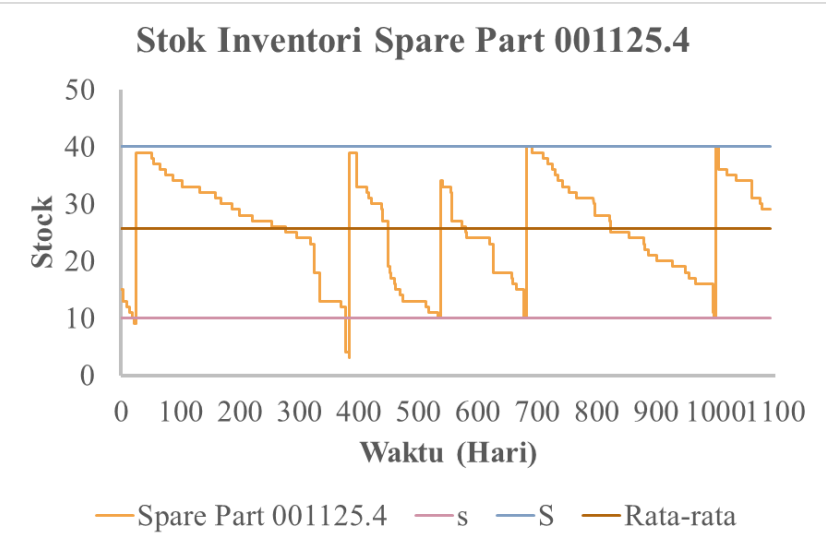

Gambar 3. Stok Persediaan Spare Part 001125.4 tahun) berjalannya simulasi, persediaan tidak pernah habis dan pemesanan selalu di bawah ROP, sehingga dapat disimpulkan bahwa spare part 001265.8 selalu tersedia dan tidak pernah kurang dari kebutuhan pada saat mesin rusak. Gambar 4 dan 5 juga menunjukkan hasil yang sama. Berdasarkan hasil eksperimen ini, maka dapat disimpulkan bahwa skenario perbaikan persediaan spare part telah optimal.

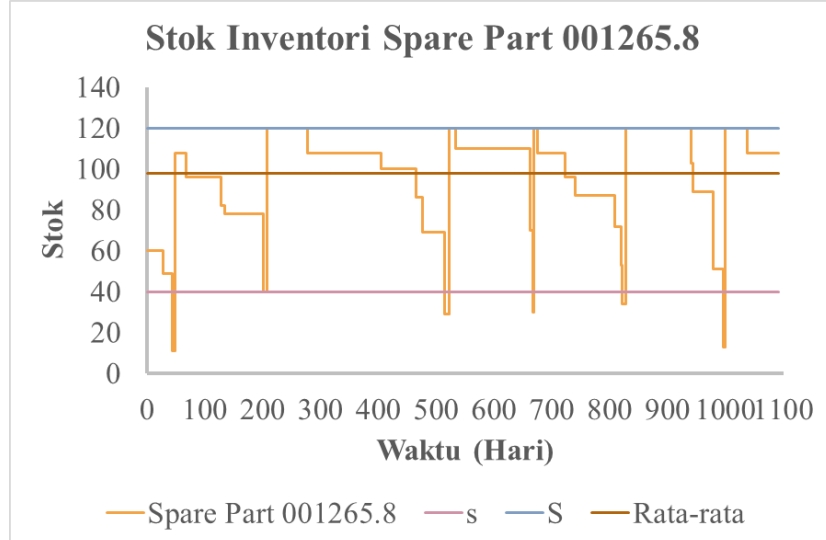

Gambar 4. Stok Persediaan Spare Part 001265.8 


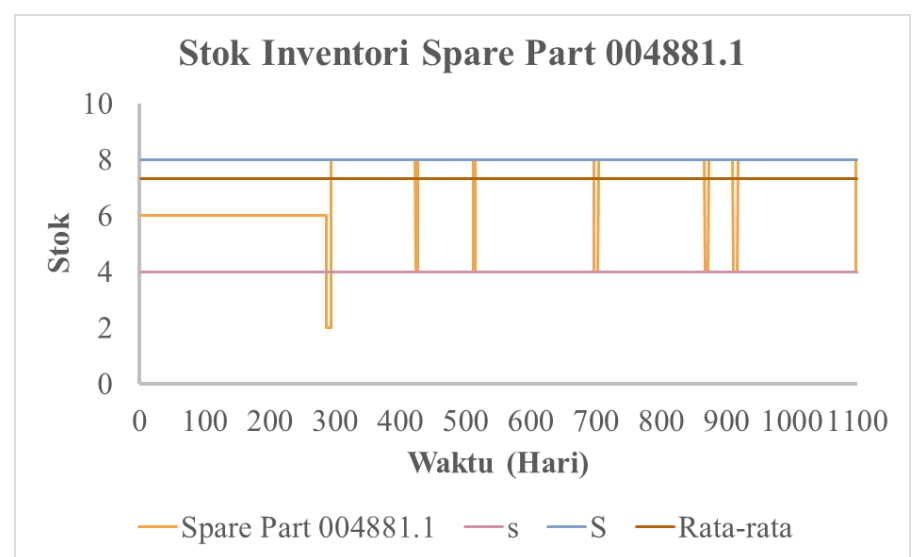

Gambar 5. Stok Persediaan Spare Part 004881.1

\section{Kesimpulan}

Pada penelitian ini telah dilakukan pemodelan simulasi untuk meningkatkan availabilitas dan meminimasi waktu produksi. Strategi yang dilakukan adalah dengan melakukan eksperimen pada persediaan spare part dan penyangga. Hasil simulasi menunjukkan bahwa kondisi eksisting waktu produksi sebesar 6.716,7 jam dan availabilitas sebesar $88,43 \%$.

Eksperimen dilakukan pada unit yang memiliki availabilitas terendah. Berdasarkan hasil simulasi, unit yang menghasilkan availabilitas terendah adalah unit oksidasi. Untuk meningkatkan availabilitas sistem, maka dilakukan eksperimen pada spare part yang memiliki availabilitas terendah di unit oksidasi. Terdapat 3 spare part yang menghasilkan availabilitas terendah, yaitu 001125.4, 001265.8, dan 004881.1. Kemudian dilakukan eksperimen $s, S$ pada masing-masing spare part. Nilai $s$ dan $S$ pada spare part 001125.4 diubah menjadi 10 dan 40. Sedangkan pada spare part 001265.8 diubah menjadi 30 dan 120 . Nilai $s, S$ pada spare part 004881.1 diubah menjadi 4 dan 8 .

Berdasarkan hasil simulasi, tidak banyak stok yang tertampung pada persediaan penyangga sehingga tidak terjadi blocking selama proses simulasi. Hal ini disebabkan karena kapasitas persediaan penyangga yang cukup besar. Oleh karena itu, persediaan penyangga ini dapat dimanfaatkan untuk menyediakan stok awal bufer. Tujuan disediakannya stok awal buffer adalah untuk menghindari terjadinya starving pada saat terjadi penutupan. Eksperimen pada persediaan penyangga dilakukan dengan menentukan stok awal persediaan penyangga, yaitu $100 \%$ dari kapasitas produksi

Berdasarkan eksperimen ini, dihasilkan waktu produksi selama 6.484 jam atau 22,5 hari setiap bulan. Pada skenario ini, waktu produksi berkurang selama 232,7 jam. atau 9,7 hari dalam setahun. Waktu produksi menurun secara signifikan tanpa adanya investasi untuk meningkatkan kapasitas produksi. Persediaan penyangga dapat ditetapkan pada awal periode produksi karena kapasitas persediaan penyangga yang tinggi dan rendahnya probabilitas terjadinya blocking. Namun, skenario ini akan menghasilkan peningkatan pada biaya operasional pada persediaan penyangga dan spare part. Biaya persediaan spare part akan meningkat karena frekuensi pemesanan yang meningkat, sedangkan biaya persediaan penyangga juga akan meningkat karena adanya aktivitas pra-produksi yang harus dilakukan untuk menyiapkan persediaan penyangga. Oleh karena itu, pada penelitian selanjutnya diharapkan dapat dilakukan analisis biaya untuk mengestimasi biaya yang dihasilkan berdasarkan skenario ini.

\section{Persantunan}

Penulis mengucapkan terima kasih yang sebesar-besarnya atas pendanaan penelitian ini dari Kementrian Riset Teknologi dan Pendidikan Tinggi melalui Skema Hibah Penelitian Tesis Magister dengan No. 780/PKS/ITS/2019. 


\section{Daftar Pustaka}

Agrawal, A. K., Murthy, V. M. S. R., \& Chattopadhyaya, S. (2019). Investigations into reliability, maintainability and availability of tunnel boring machine operating in mixed ground condition using Markov chains. Engineering Failure Analysis, 105, 477-489. https://doi.org/10.1016/j.engfailanal.2 019.07.013

Ahmadi, S., Moosazadeh, S., Hajihassani, M., Moomivand, H., \& Rajaei, M. M. (2019). Reliability, availability and maintainability analysis of the conveyor system in mechanized tunneling. Measurement, 145, 756764.

https://doi.org/10.1016/j.measurement. 2019.06.009

Chang, P.-C. (2017). A simulation analysis of the impact of finite buffer storage on manufacturing system reliability. Simulation Modelling Practice and Theory, 70, 149-158. https://doi.org/10.1016/j.simpat.2016. 10.006

Chang, P.-C., Lin, Y.-K., \& Chiang, Y.-M. (2019). System reliability estimation and sensitivity analysis for multi-state manufacturing network with joint buffers-A simulation approach. Reliability Engineering \& System Safety, 188, 103-109. https://doi.org/10.1016/j.ress.2019.03. 024

Corvaro, F., Gianchetta, G., Machetti, B., \& Recanati, M. (2017). Reliability, Availability, Maintainability (RAM) Study on Reciprocating Compressors. Petroleum, 3, 266-272.

Elusakin, T., \& Shafiee, M. (2020). Reliability analysis of subsea blowout preventers with condition-based maintenance using stochastic Petri nets. Journal of Loss Prevention in the Process Industries, 63, 104026. https://doi.org/10.1016/j.jlp.2019.1040 26
Faulin, J., Juan, A. A., Martorell, S., \& Marquez, J.-E. R. (2010). Simulation Methods for Reliability and Availability of Complex Systems. Springer Series in Reliability Engineering.

Fiondella, L., Lin, Y.-K., Pham, H., Chang, P.-C., \& Li, C. (2017). A confidencebased approach to reliability design considering correlated failures. Reliability Engineering \& System Safety, 165, 102-114. https://doi.org/10.1016/j.ress.2017.03. 025

Gebennini, E., Grassi, A., Fantuzzi, C., \& Rimini, B. (2017). Discrete time model of a two-station one-buffer serial system with inventory leveldependent operation. Computers \& Industrial Engineering, 113, 46-63. https://doi.org/10.1016/j.cie.2017.09.0 07

Halfpenny, A., Chabod, A., Czapski, P., Aldred, J., Munson, K., \& Bonato, M. (2019). Probabilistic Fatigue and Reliability Simulation. Procedia Structural Integrity, 19, 150-167. https://doi.org/10.1016/j.prostr.2019.1 2.018

Harrel, C., Gosh, B. K., \& Bowden, R. O. (2004). Simulation Using Promodel (2nd ed.). Mc. Graw Hill.

Jiang, Y., Chen, M., \& Zhou, D. (2015). Joint optimization of preventive maintenance and inventory policies for multi-unit systems subject to deteriorating spare part inventory. Journal of Manufacturing Systems, 35, 191-205.

https://doi.org/10.1016/j.jmsy.2015.01 .002

Kaczor, G., Młynarski, S., \& Szkoda, M. (2016). Verification of safety integrity level with the application of Monte Carlo simulation and reliability block diagrams. Journal of Loss Prevention in the Process Industries, 41, 31-39. https://doi.org/10.1016/j.jlp.2016.03.0 02 
Kementrian Perindustrian Indonesia. (2017). Laporan Ekspor Impor Industri Pengolahan Indonesia 2017.

Mahdi, I., Chalah, S., \& Nadji, B. (2017). Reliability study of a system dedicated to renewable energies by using stochastic petri nets: Application to photovoltaic (PV) system. Energy Procedia, 136, 513-520. https://doi.org/10.1016/j.egypro.2017. 10.276

Nzukam, C., Voisin, A., Levrat, E., Sauter, D., \& Iung, B. (2018). Opportunistic maintenance scheduling with stochastic opportunities duration in a predictive maintenance strategy. IFAC-PapersOnLine, 51(11), 453458.

https://doi.org/10.1016/j.ifacol.2018.0 8.348

Rao, M. S., \& Naikan, V. N. A. (2016). Review of Simulation Approaches in Reliability and Availability Modeling. 12(4), 369-388.

Sabouhi, H., Abbaspour, A., FotuhiFiruzabad, M., \& Dehghanian, P. (2016). Reliability modeling and availability analysis of combined cycle power plants. International Journal of Electrical Power and Energy Systems, 79, 108-119. https://doi.org/10.1016/j.ijepes.2016.0 1.007

Salsabila, N. Y., \& Siswanto, N. (2019). A Simulation Study of Availability Analysis on a Chemical Process Industry Considering Spare Part Inventory. IOP Conference Series: Materials Science and Engineering.

Salsabila, N. Y., Siswanto, N., Widodo, E., \& Rochmadhan, O. A. (2019). Throughput Analysis on a Multi-state Manufacturing System by Considering Availability. Jurnal Teknik Industri, 21(2), 69-78. https://doi.org/10.9744/jti.21.2.69-78

Sheikh-Zadeh, A., Farhangi, H., \& Rossetti, M. D. (2020). Inventory grouping and sensitivity analysis in multi-echelon spare part provisioning systems.
Computers \& Industrial Engineering, 143, 106230. https://doi.org/10.1016/j.cie.2019.106 230

Sleptchenko, A., \& van der Heijden, M. (2016). Joint optimization of redundancy level and spare part inventories. Reliability Engineering \& System Safety, 153, 64-74. https://doi.org/10.1016/j.ress.2016.04. 006

Trigueiro de Sousa Junior, W., Barra Montevechi, J. A., de Carvalho Miranda, R., \& Teberga Campos, A. (2019). Discrete simulation-based optimization methods for industrial engineering problems: A systematic literature review. Computers \& Industrial Engineering, 128, 526-540. https://doi.org/10.1016/j.cie.2018.12.0 73

U.S. Department of Energy. (2014). Definitions, Sources and Explanatory Notes Cateogry Petroleum Refining \& Processing Topic Refinery Utilization \& Capacity. Definitions, Sources, and Explanatory Notes of Petroleum \& Other Liquid's Refinery Utilization and Capacity. https://www.eia.gov/dnav/pet/TblDefs /pet_pnp_unc_tbldef2.asp

Wang, J., Zhang, Q., Yoon, S., \& Yu, Y. (2019). Reliability and availability analysis of a hybrid cooling system with water- side economizer in data center. Building and Environment, 148(November 2018), 405-416. https://doi.org/10.1016/j.buildenv.201 8.11.021

Wen, M., Han, Q., Yang, Y., \& Kang, R. (2017). Uncertain optimization model for multi-echelon spare parts supply system. Applied Soft Computing, 56, 646-654.

https://doi.org/10.1016/j.asoc.2016.07. 057

Xiang, M., Rossi, R., Martin-Barragan, B., \& Tarim, S. A. (2018). Computing nonstationary $(\mathrm{s}, \mathrm{S})$ policies using mixed integer linear programming. European 
Journal of Operational Research, 271(2), $\quad$ 490-500. https://doi.org/10.1016/j.ejor.2018.05. 030

Zhu, S., Jaarsveld, W. van, \& Dekker, R. (2020). Spare parts inventory control based on maintenance planning. Reliability Engineering \& System Safety, 193, 106600. https://doi.org/10.1016/j.ress.2019.106 600 